\title{
Picloram groundwater contamination from pasture use ${ }^{1,2}$
}

\author{
Lii-chyuan Liu', José A. Dumas and Carmen L. Cacho'
}

J. Agric. Univ. P.R. 81(3-4):211-218 (1997)

\begin{abstract}
The adsorption of picloram was studied in 28 pasture soils under laboratory conditions. The adsorptive capacities of these soils were expressed in terms of the empirical constants, $K$ and $1 / n$ of the Freundlich equation. The calculated $K$ values ranged from 0.269 to 1.842 for Espinosa sandy loam and Bajura clay, respectively. The $1 / \mathrm{n}$ values ranged from 0.27 to 1.68 for Carrizales sandy loam and Mabí clay, respectively. The $\mathrm{K}$ values were negatively correlated with sand content of these pasture soils, and positively correlated with organic matter content, cation exchange capacity, clay content and silt content of the soils. In a field study on picloram groundwater contamination from pasture use, picloram at $2.47 \mathrm{~L} / \mathrm{ha}$ was applied twice to two pasture plots (Mabi clay loam). Water samples were collected weekly from two wells adjacent to these pasture plots for three months after each herbicide application. All water samples were analyzed by gas chromatography. No detectable level of picloram concentration was found in any of the water samples collected after the first herbicide application. However, a very low level of picloram $(2 \mu \mathrm{g} / \mathrm{L})$ was detected in one of the wells 10 weeks after the second herbicide application. This finding suggests that there is little possibility that picloram will contaminate groundwater in a heavy soil such as Mabí clay loam.
\end{abstract}

Key words: Picloram, groundwater, contamination

\section{RESUMEN}

Contaminación de las aguas subterráneas por el uso de picloram en pastos

Se realizó un estudio de adsorción de picloram en 28 suelos de pastoreo bajo condiciones de laboratorio. Las capacidades de estos suelos para adsorber el picloram se expresaron en términos de las constantes de $K$ y $1 / n$ de la ecuación de Freundlich. Las constantes de adsorción (K) de estos suelos variaron desde 0.269 a 1.842 en el suelo Espinosa limo arenoso y en

Manuscript submitted to Editorial Board 27 March 1995.

"We would like to thank the Water Resources Research Institute, College of Engineering, University of Puerto Rico for financial support in conducting this research. We greatly appreciate the assistance of Extension agents Manuel Diaz Rivera, Juan A. Cortés, José Nabor Muñoz, Mildred Pérez Aponte, Moisés Díaz Medina, and Ramón Martinez Zayas in collecting soil samples from different pasture fields used in our adsorption study. We are grateful for the technical assistance of Jose A. Rodriguez of U.S. Geological Survey in collecting water samples for groundwater contamination study.

"Plant Physiologist, Assistant Chemist, Agricultural Experiment Station, Crop Protection Department, College of Agricultural Sciences, University of Puerto Rico, Mayagüez Campus.

'Chemist, US Customs Service, San Juan, P.R. 
el Bajura arcilloso, respectivamente. Se hizo un análisis de correlación entre los valores de $\mathrm{K}$ de suelos para pastoreo y sus respectivas propiedades físicas y químicas. Los valores de $\mathrm{K}$ de los suelos se correlacionaron negativamente con su contenicio de arena y positivamente con su contenido de materia orgánica, arcílla, limo y capacidad de intercambio de cationes. En un estudio de campo sobre la contaminación de agua subterránea con picloram, éste se aplicó dos veces a la dosis de $2.47 \mathrm{~L} / \mathrm{ha}$ a dos parcelas de pasto (Mabi limo arcilloso), cada una de ellas adyacente a un pozo de agua. Las muestras de agua se recogieron semanalmente por un periodo de tres meses. Se analizaron las muestras con un cromatógrafo de gas. No se detectó picloram después de la primera aplicacion Sin embargo, se detectó una concentración de $2 \mu \mathrm{g} / \mathrm{L}$ en uno de los pozos 10 semanas después de la segunda aplicación. Este hallazgo sugiere que hay poca posibilidad de contaminar agua subterránea con picloram en los suelos pesados parecidos al Mabi limo arcilloso.

\section{INTRODUCTION}

Picloram is used for selective control of broadleaf and woody plants in Puerto Rican pastures. Some 17,657 L of picloram was sold locally in 1993 for pasture use. 5 There is considerable documented information on groundwater contamination by picloram in the United States (US Environmental Protection Agency, 1988a; 1988c) and it has been identified by the Environmental Protection Agency as a pesticide with a great tendency to leach into groundwater (USEPA,1988a). Picloram was classified as a "restricted use pesticide" in 1978. The 1985 EPA standard retained the picloram advisory statement included on the label. This herbicide has been detected in groundwater in seven states of the U.S. (USEPA 1988a). The contamination has been associated with normal field use of picloram. In studies on ground water contamination, Smith et al. (1988) found that picloram application to sandy soil, with water table at a 1 -m depth, led to a picloram level of up to $438 \mu \mathrm{g} /$ $\mathrm{L}$ in groundwater 26 months after treatment. Watson et al. (1989) found that rapid penetration of picloram after application to roadside weeds led to a detectable level of $20 \mu \mathrm{g} / \mathrm{L}$ at 75 to $100-\mathrm{cm}$ depth in seven days. On the other hand, Neary et al. (1985) and Haas et al. (1971) detected only traces or no picloram at all in their respective studies. The prevailing high rainfall conditions of Puerto Rico would make picloram more apt to contaminate groundwater than conditions encountered in the United States. Sometimes, repeated picloram applications to pasture fields are needed to sustain weed control. Therefore, we are concerned about the negative impact of picloram on water quality in Puerto Rico.

f 'astañer, L. F, 1993. Personal communication. (Sales Managex of' Ochoa Fertiljzer Co., Representative of Dow-Elanco Chemical Co.). 
The adsorption of picloram on soils is one of the important factors influencing its leaching loss into groundwater. The information on adsorptive capacities of 28 pasture soils to adsorb picloram would enable us to identify specific soils which might be vulnerable to picloram groundwater contamination. The level of picloram detected from the selected wells would give us an indication as to the need for more extensive studies on this subject. The objectives of this investigation are: 1) to determine the magnitude of picloram adsorption by pasture soils; 2) to determine the levels of picloram groundwater contamination in two selected wells.

\section{MATERIALS AND METHODS}

Adsorption study

For fulfilling the first objective, a total of 28 soil samples (at 0 to 15 $\mathrm{cm}$ ) were collected from different pasture fields with no past history of picloram usage. Two of these soils were taken from an area adjacent to well sites at the Gurabo substation (AES), the sites of the picloram groundwater contamination study. The collected soils were air dried, pulverized, sieved (No. 10 sieve) and stored for the adsorption study. One gram of each soil was weighed in a small centrifuge tube and shaken with $10 \mathrm{ml}$ of picloram solution for $18 \mathrm{~h}$. A stock solution of picloram $(50 \mathrm{mg} / \mathrm{L})$ was prepared in de-ionized distilled water in a volumetric flask. Subsequent dilutions were made to contain a concentration series of $2.5,5.0,7.5,10.0$ and $15.0 \mathrm{mg} / \mathrm{L}$ of picloram. Afterward, each tube was centrifuged at 5,000 rpm for 20 minutes. Five $\mathrm{ml}$ of supernatant was used for diazotizing with $1 \mathrm{ml} 0.1 \mathrm{M} \mathrm{NaNO}$ and $1 \mathrm{ml}$ concentrated $\mathrm{H}_{2} \mathrm{SO}_{4}$, for color development; solution was mixed and centrifuged for 10 minutes at 3,500 rpm. Absorbance was read at 405 $\mathrm{nm}$ on a spectrometer by the method of Cheng (1969). All adsorption determinations were made in triplicate. The Freundlich equation was used to describe the adsorption processes between the adsorbate and the adsorbent.

$$
\mathrm{X} / \mathrm{M}=\mathrm{KC}^{\mathrm{z} / \mathrm{n}}
$$

or

$$
\log x / m=\log K+1 / n \log C
$$

where $\mathrm{X} / \mathrm{M}$ is $\mu \mathrm{g}$ picloram per gram of soil, $\mathrm{C}$ is the picloram equilibrium concentration $(\mu \mathrm{g} / \mathrm{ml})$ and $\mathrm{K}$ and $\mathrm{n}$ are constants. Logarithmic plot of $\mathrm{x} / \mathrm{m}$ against $\log \mathrm{C}$, produces a linear relationship. $K$ values equal $\log \mathrm{x} / \mathrm{m}$ at $\mathrm{C}=1.00 \mu \mathrm{g} / \mathrm{ml}$. These $\mathrm{K}$ constants for different soils could 
serve as a guide for comparing the leaching potential of picloram in different pasture soils.

Field study

For fulfilling the second objective, two observation wells at Gurabo Experimental Substation owned by the U.S. Geological Survey were used for conducting the picloram groundwater contamination study. Well \#1 has a plastic casing, with a diameter of $10 \mathrm{~cm}$ and a depth of 14 $\mathrm{m}$. Well \#2 has a steel casing with a diameter of $33 \mathrm{~cm}$ and a depth of $44 \mathrm{~m}$. Stargrass (Cynodon nlemfuensis) was the major pasture grass at the well sites. As a control, we collected $15 \mathrm{~L}$ of water from each well before the picloram application. The first picloram application at $2.47 \mathrm{~L} /$ ha was made with a knapsack sprayer fitted with a Teejet 8003 nozzle tip as a simulated spot treatment on 20 September 1993. The size of pasture plot was $21.3 \times 24.4 \mathrm{~m}$. The soil series for well \#1 and well \#2 were Mabí clay loam and Mabi clay, respectively. The second picloram application at the same rate was made on 6 July 1994. Water samples were collected weekly with a bailer and stored in 3.8-L amber colored glass bottles for transportation to the laboratory. A subsampling was made at the laboratory and a $250-\mathrm{ml}$ portion was stored in a refrigerator until analysis. The level of picloram in the water samples was analyzed for three months after each herbicide application. Picloram analysis was done by acidifying $100 \mathrm{ml}$ water samples with concentrated HCL and by extracting with ethylether. The ether extract was evaporated in a steam bath and esterified with $5 \mathrm{ml}$ of $12.5 \%$ boron trifluoside methanol solution. The methylated sample was dissolved in 10 $\mathrm{ml}$ of hexane and added to $10 \mathrm{ml}$ of water. The hexane extract was recovered and a portion was injected into the chromatograph as described by Trichell (1968) and Zweig (1972). The water samples collected from the first picloram application were analyzed by a Tracor $56^{6}$ gas chromatograph. This gas chromatograph was equipped with a ${ }^{6:} \mathrm{N}$ electron capture detector with a $1.8-\mathrm{ml}$ spiral glass column. The glass column was packed with $3 \%$ dimethanol cyclobexane succinate (DMCS) on 80 to 100 mesh chromosorb Q. The temperatures used for injector, column, and detector for analyzing picloram extracts were 250,180 and $300^{\circ} \mathrm{C}$, respectively. The detection limit for this chromatograph was $3 \mu \mathrm{g} / \mathrm{L}$. A new SHIMADZU GC-17A gas chromatograph was used for analyzing those water samples collected from the second picloram application. The detection limit for this gas chromatograph was $1.0 \mu \mathrm{g} / \mathrm{L}$.

${ }^{-}$Mention of a trade name does not constitute a waranty of equipment or materials by the Agricultural Experiment Station of the University of Puerto Rico, nor is this mention a statement of preference over other equipment or materials. 


\section{RESULTS AND DISCUSSION}

\section{Adsorption study}

The highest picloram adsorption in terms of $\mathrm{K}$ value was obtained with Bajura clay (1.842) and the lowest $\mathrm{K}$ value with Espinosa sandy loam (0.269) (Table 1 ). The $1 / \mathrm{n}$ value for different soils ranged from 0.27 to 1.67 (Table 1). Table 2 presents physical and chemical properties of the 28 soils which were used in our correlation study. The $\mathrm{K}$ values for picloram were found to correlate negatively with sand contents of the pasture soils, but positively with organic matter, cation exchange ca-

TABLE 1. - Freundlich constants $K$ and $1 / n$ of picloram on 28 Puerto Rican pasture soils.

\begin{tabular}{lll}
\hline Soil & \multicolumn{1}{c}{$\mathrm{K}$} & $1 / \mathrm{r}$ \\
\hline Aceituna clay & $1.406 \mathrm{abc}$ & 1.16 \\
Almirante sandy loam & $1.359 \mathrm{abc}$ & 0.63 \\
Bajura clay & $1.842 \mathrm{a}$ & 0.76 \\
Bayamón clay & $1.075 \mathrm{~cd}$ & 0.65 \\
Caguabo clay & $1.494 \mathrm{abc}$ & 1.23 \\
Carrizales sandy loam & $0.286 \mathrm{e}$ & 0.27 \\
Colina sandy clay loam & $1.250 \mathrm{bcd}$ & 0.92 \\
Coloso clay & $1.454 \mathrm{abc}$ & 1.00 \\
Coloso silty clay loam & $1.385 \mathrm{abc}$ & 0.65 \\
Corozal clay & $1.708 \mathrm{ab}$ & 0.91 \\
Coto clay & $1.463 \mathrm{abc}$ & 0.83 \\
Espinosa sandy loam & $0.269 \mathrm{e}$ & 0.28 \\
Fajardo loam & $1.509 \mathrm{abc}$ & 1.03 \\
Fajardo clay loam & $1.578 \mathrm{abc}$ & 0.85 \\
Fraternidad clay & $1.412 \mathrm{abc}$ & 0.87 \\
Guayabo sandy loam & $0.276 \mathrm{e}$ & 0.69 \\
Humata clay & $1.684 \mathrm{ab}$ & 0.79 \\
Jobo sandy loam & $0.784 \mathrm{e}$ & 0.97 \\
Mabí clay & $1.408 \mathrm{abc}$ & 1.68 \\
Mabí clay loam & $1.472 \mathrm{abc}$ & 1.00 \\
Múcara clay & $1.627 \mathrm{abc}$ & 0.95 \\
Naranjito clay & $1.404 \mathrm{abc}$ & 1.03 \\
Pandura loam & $1.307 \mathrm{abcd}$ & 0.81 \\
Río Arriba clay & $1.357 \mathrm{abc}$ & 1.13 \\
San Antón loam & $1.337 \mathrm{abc}$ & 0.71 \\
San Germán sandy loam & $1.552 \mathrm{abc}$ & 0.87 \\
Toa clay & $1.434 \mathrm{abc}$ & 0.79 \\
Torres clay & $1.477 \mathrm{abc}$ & 0.55 \\
& & \\
& &
\end{tabular}

${ }^{2}$ Means followed by the same letters do not differ significantly at $\mathrm{P}<0.05$. 
TABLE 2.-Properties of 28 Puerto Rican pasture soils used in adsorplion of picloram studies.

\begin{tabular}{|c|c|c|c|c|c|c|}
\hline Soils & pH & $\begin{array}{c}\text { Organic } \\
\text { matter } \\
\%\end{array}$ & $\begin{array}{c}\mathrm{CEC} \\
\mathrm{cmol} / \mathrm{kg}\end{array}$ & $\begin{array}{c}\text { Clay } \\
\%\end{array}$ & $\begin{array}{l}\text { Silt } \\
\%\end{array}$ & $\begin{array}{c}\text { Sand } \\
\%\end{array}$ \\
\hline Aceituna clay & 4.90 & 1.78 & 6.79 & 40.97 & 41.82 & 17.21 \\
\hline Almirante sandy loam & 6.32 & 2.69 & 7.48 & 13.27 & 10.66 & 76.07 \\
\hline Bajura clay & 6.33 & 3.03 & 30.09 & $\$ 1.62$ & 27.16 & 31.22 \\
\hline Bayamón clay & 5.14 & 2.02 & 16.27 & 60.58 & 23.94 & 15.48 \\
\hline Caguabo clay & 8.09 & 5.37 & 34.17 & 49.18 & 28.56 & 22.26 \\
\hline Carrizales sandy loam & 8.35 & 0.79 & 3.45 & 12.63 & 9.98 & 77.39 \\
\hline Colina sandy day loam & 8.18 & 3.16 & 16.82 & 23.61 & 19.98 & 56,41 \\
\hline Coloso clay & 7.20 & 2.31 & 23.18 & 44.07 & 30.88 & 25.05 \\
\hline Coloso silty clay Joam & 8.09 & 1.87 & 28.55 & 41.06 & 30.19 & 28.75 \\
\hline Corozal clay & 4.92 & 2.37 & 14.04 & 59.16 & 22.58 & 18.26 \\
\hline Coto clay & 7.44 & 2.10 & 8.96 & 41.32 & 22.71 & 35.97 \\
\hline Espinosa sandy loam & 7.08 & 1.05 & 3.13 & 18.06 & 17.00 & 64.94 \\
\hline Fajardo loam & 5.59 & 3.76 & 12.33 & 31.29 & 32.57 & 36.14 \\
\hline Fajardo clay loam & 5.05 & 4.51 & 11.90 & 34.23 & 37.41 & 28.36 \\
\hline Fraternidad clay & 7.18 & 1.40 & 39.67 & 50.45 & 27.32 & 22.23 \\
\hline Guayabo sandy loam & 7.14 & 1.92 & 8.87 & 14.96 & 10.27 & 74.77 \\
\hline Humata clay & 5.84 & 1.72 & 9.53 & 69.74 & 15.78 & 14.48 \\
\hline Jobos sandy loam & 8.28 & 1.45 & 3.65 & 17.09 & 16.55 & 66.36 \\
\hline Mabí clay & 6.16 & 3.95 & 26.26 & 60.46 & 20.83 & 18.71 \\
\hline Mabí clay loam & 6.27 & 4.09 & 23.31 & 29.99 & 33.84 & 36.77 \\
\hline Múcara clay & 7.85 & 2.79 & 12.58 & 69.56 & 22.48 & 7.96 \\
\hline Naranjito clay & 5.48 & 2.59 & 11.28 & 71.68 & 18.36 & 9.96 \\
\hline Pandura loam & 6.68 & 1.74 & 11.29 & 24.64 & 44.19 & 31.17 \\
\hline Río Arriba clay & 5.60 & 2.79 & 6.10 & 41.60 & 34.09 & 24.31 \\
\hline San Antón loam & 7.22 & 1.31 & 20.25 & 31.07 & 32.86 & 36.07 \\
\hline San Germán sandy loam & 8.14 & 3.09 & 6.48 & 11.98 & 23.61 & 64.36 \\
\hline Toa clay & 8.05 & 3.08 & 25.59 & 36.73 & 37.41 & 25.86 \\
\hline Torres day & 8.11 & 2.31 & 7.54 & 49.32 & 17.35 & 33.33 \\
\hline
\end{tabular}

pacity (CEC), clay contents and silt contents (Table 3). These results are in agreement with work done by Farmex and Aochi (1974), Grover (1971) and Hamaker et al. (1968). They reported that adsorption of picloram increased with increasing organic matter of the soil. The lack of a significant correlation between picloram adsorption and $\mathrm{pH}$ found in this study is in keeping with the results of Farmer and Aochi (1974). They found that picloram adsorption was not significantly correlated with $\mathrm{pH}$ in the range of 5.6 to 7.4. The highly negative correlation found between picloram adsorption and sand content indicates that picloram 
TABLE 3.-Simple correlation of soil properties among themselves and with $K$ values of picloram of their corresponding soils.

\begin{tabular}{lcccccc} 
Factors correlated & pH & $\begin{array}{c}\text { O.M. } \\
\%\end{array}$ & $\begin{array}{c}\text { CEC } \\
\text { cmol/kg }\end{array}$ & $\begin{array}{c}\text { Clay } \\
\%\end{array}$ & $\begin{array}{c}\text { Silt } \\
\%\end{array}$ & $\begin{array}{c}\text { Sand } \\
\%\end{array}$ \\
\hline K value for picloram & -0.2882 & 0.5079 & 0.4117 & 0.5466 & 0.4644 & -0.6764 \\
pH & 1.0000 & -0.1478 & 0.1120 & -0.3773 & -0.2753 & 0.4422 \\
Organic matter & -0.1483 & 1.0000 & 0.3605 & 0.1787 & 0.2499 & -0.2613 \\
CEC & 0.1120 & 0.3600 & 1.0000 & 0.3343 & 0.3350 & -0.4355 \\
Clay & -0.3773 & 0.1580 & 0.3343 & 1.0000 & 0.0800 & -0.8979 \\
Silt & -0.2753 & 0.2839 & 0.3350 & 0.0800 & 1.0000 & -0.5106 \\
Sand & 0.4422 & -0.2604 & -0.4355 & -0.8979 & -0.5106 & 1.0000
\end{tabular}

Correlation coefficients differ significanlly at $5 \%=0.36$, at $1 \%=0.47$.

groundwater contamination is more likely to occur in light-textured soils in Puerto Rico. Picloram is only weakly adsorbed by these soils.

Field study

None of the water samples from the two wells, collected weekly for three months after the first picloram application, contained a detectable level of picloram $(3 \mu \mathrm{g} / \mathrm{L})$. Those water samples were analyzed again for picloram with a SHTMADZU GC-17A gas chromatograph. No detectable level of picloram $(1 \mu \mathrm{g} / \mathrm{L})$ was found in any of the water samples collected for three months after the first picloram application. Nor was any detectable level of picloram $(1 \mu \mathrm{g} / \mathrm{L})$ found in water samples collected for three months after the second picloram application, with the exception of one sample which contained a level of $2 \mu \mathrm{g} / \mathrm{L}$ of picloram. This water sample was collected from well \#1 ten weeks after the second picloram application. This result suggests that there is little possibility for picloram to contaminate groundwater when applied to a heavy Mabí clay loam. The K values for picloram in well soil (Mabí clay loam) was determined to be 1.472 . This $\mathrm{K}$ value of Mabi clay loam could serve as a relative guide to be compared with $\mathrm{K}$ values of other pasture soils for whose degrees of groundwater contamination are unknown. We might assume that those soils with $\mathrm{K}$ values significantly lower than 1.472 would be more likely to get a higher than $2 \mu \mathrm{g} / \mathrm{L}$ of picloram groundwater contamination.

Since picloram possesses a low mammalian toxicity (USEPA, 1988b), EPA has established a maximum permissible level in drinking water of $500 \mu \mathrm{g} / \mathrm{L}$ (Anonymous, 1994). The level of $2 \mu \mathrm{g} / \mathrm{L}$ of picloram detected in well \#1 from our field experiment would pose no risk to human health. However, a level of $1 \mu \mathrm{g} / \mathrm{L}$ of picloram is known to cause 
phytotoxicity to sensitive crops such as tomatoes, potatoes, and legumes (USEPA, 1988a). To avoid injury to these sensitive crops, farmers should not use picloram in light-textured soils.

\section{LITERATURE CITED}

Anonymous, 1994. Environmental Handbook. A Miester Publication. Willoughby, OH 44094.

Cheng, H. H., 1969. Extraction and colorimetric determination of picloram in soil. J. Ag. ric. Food Chem. 17(4):1174-1177.

Farmer, W. J. and Y. Aochi, 1974. Picloram sorption by soils. Soil Sci. Soc. Amer: Proc. $38: 418-423$.

Grover, R., 1971. Adsorption of picloram by soil colloids and various other adsorbents. Weed Sci. 19:417-418.

Haas, H. H., C. J. Scrifres, M. G. Merekle, R. R. Rahn and G. C. Hoftman, 1971. Occurrence and persistence of picloram in grassland water sources. Weed Res. 8:292-297.

Hamaker, J. W., C. A. I. Goring and C. R. Youngson, 1968. Sorption and leaching of picloram in soils, p. 23-37. In: Organic pesticides in environment. Advances in Chemistry Series 60. Amer. Chem. Soc. Washington, D.C.

Hamaker, J. W., C. A. I. Goring, C. R. Youngson and J. W. Hamaker, 1965. Tordon herbicide: Disappearance from soils. Down to Earth 20(4):3-5.

Neary, D. G., P. B. Bush, J. E. Douglas and R. L. Todd, 1985. Picloram movement in an Appalachian hardwood forest watershed. J. Environ. Qual. 14:565-592.

Smith, A. E., D. Waite, R. Grover, L. A. Kerr, L. J. Milard and H. Sommerstad, 1988. Persistence and movement of picloram in a northern Saskachewan watershed. J. Environ. Qual. 17:262-268.

Trichell, D. W., H. L. Morton and M. G. Merkle, 1968. Loss of herbicides in runoff wates: Weed Sci. 16:442-449.

U.S. Environmental Protection Agency, 1988a. Pesticides in Ground Water: Background Document. Office of Ground Water Protection. Washington D.C. 20460.

U.S. Environmental Protection Agency, 1988b. Pesticide Fact Handbook. p. 646. Noyes Data Corporation. Park Ridge, N.J.

U.S. Environmental Protection Agency, 1988c. Guidance for the reregistration of pesticide products containing picloram as the active ingredient. Office of Pesticides and Toxic Substances. Washington D.C. 20460.

Watson, V. J., P. M. Rice and E. C. Monnig, 1989. Environmental fate of picloxam use for roadside weed control. I. Environ. Qual. 18:198-205.

Zweig, G., 1972. Analytical methods for pesticide, plant growth regulators and food additives. VI Gas Chromatography analysis. Academic Press, New York and London. 